\title{
Forced Relocations, Memory and Nostalgia amongst Indian South Africans in Post- Apartheid South Africa
}

\section{K. Gopalan}

\begin{abstract}
Relocations resulting from forced removals, during the implementation of the Group Areas Act (GAA) of 1950, have had profound implications on the ways in which South Africans see themselves today influencing both insular identities and broader notions of citizenship. This paper focuses specifically on Indian Municipal employees of the Durban Corporation (DC) who were removed from the Durban Municipal Magazine Barracks (henceforth Magazine Barracks) and resettled in Chatsworth, by examining the meaning of 'Magazine Barracks' on its former residents today, almost six decades after its destruction. Although the Magazine Barracks was established for the capitalist motives of the DC to house a cheap and manageable labour force, residents responded to circumstances imposed upon them by creating a unique lifestyle within the Magazine Barracks, which they revere today. They gave names to areas which comprised the Magazine Barracks and took advantage of their overcrowded living conditions to create notions of closeness through religious and cultural institutions, and produced a rich sporting and academic heritage. When the Magazine Barracks was destroyed by the GAA, residents similarly responded to structural forces imposed upon them in unique ways and examining this history provides valuable insight into how the past is negotiated in the present to shape identity.
\end{abstract}

Keywords: Magazine Barracks; memory; forced removals; Indian; and Chatsworth 


\section{Introduction}

South Africa's first democratic election in April 1994 was characterised by euphoria and optimism. The aim of creating a rainbow nation was seen as a means to unite a diverse nation. However, the long lasting impact of colonialism and nearly five decades of Apartheid were far reaching in dividing South Africans and entrenched massive inequalities. The so-called 'miracle' of South Africa's transformation of 1994, which now appears to be unravelling two decades into the post-apartheid period, has had very different outcomes for South Africans and the country remains highly stratified. This makes it all the more important in the present juncture to critically engage with the past and analyse how various structural forces have come to influence people's identities.

This paper examines the experiences and the memories of forced removals and relocation on former residents of the Magazine Barracks, to reflect on ways in which one group of South Africans are negotiating the past in the present and how the various laws imposed upon them affected their past lives and remain powerful in influencing their identities in the present. The Magazine Barracks were built in the 1880s on Somtseu Road just north of the Durban central business district (CBD), to house Indian municipal workers and their families. During the implementation of the GAA during the 1960s, approximately 10000 people were removed from the Magazine Barracks and relocated to Chatsworth, 20 kilometres south west of the CBD. The Magazine Barracks was demolished thereafter and is currently the site of a police headquarters and magistrates' courts.

Those that were forcibly removed from the Magazine Barracks faced many social and economic challenges as they made the transition to Chatsworth. This study explores how, over the long term, Group Areas relocations influenced the lives of these individuals and their families. It thus seeks to deepen our understanding of how broad structural changes in South Africa's complex history during the middle decades of the twentieth century are reflected through the subjective experiences and agency of ordinary people. Equally important, the study brings into the equation the agency and subjectivity of the 'victims' of the GAA. In order to do this, the paper begins with a brief discussion on oral history and the challenges of using human memory as a historical source before a providing a very brief background of the Group Areas Act. Thereafter the paper focuses on the creation of the 


\section{K. Gopalan}

Magazine Barracks to highlight how residents created an identity associated with the Magazine Barracks and finally examines what oral testimonies of particular residents today, can tell us about the meaning of that identity nearly five decades after the destruction of the Magazine Barracks.

\section{Memory, Nostalgia and Oral History}

A theme that emerged during the research process was that despite it being more than half a century since the destruction of the Magazine Barracks, some former residents continued to refer to it as their 'home' and many contended that a Magazine Barracks 'community' still exists today. Although the buildings that made up the Magazine Barracks have been destroyed, the name still has intrinsic value in the lives of its former residents and their identities. This is maintained through webs of friendships and social practices. Katja Uusihakala (2008: 2) who examined the memories of white former residents of Rhodesia (now Zimbabwe), who emigrated to South Africa after British colonial rule came to an end in 1980, wrote that 'social practices connected with processes of remembering together are constitutive of how the community understands itself'.

Like many other communities who experienced displacement, commemorative memory, or the act of remembering together, features strongly amongst former residents of the Magazine Barracks (See Trotter 2009). This was evident during oral interviews with former residents and is illustrated in the efforts of bodies such as the Magazine Barracks Remembrance Association (MBRA) which holds meetings from time to time to find ways of preserving the memory of the Magazine Barracks, and the Durban Municipal Pensioners' Club which organises weekly meetings where former residents socialise. At the Club's weekly meetings and mass meetings organised by the MBRA, former residents often reminisce about their time in the Magazine Barracks. At the time of writing, the most recent mass meeting of former residents had taken place on 8 November 2014 at the Chatsworth Youth Centre and was attended by more than 700 former residents of the Magazine Barracks.

Kiru Naidoo (2012), one of the study respondents, believes that there is an important story to tell about Chatsworth as a journey of progression, but advocates an insider perspective.

I was born in Chatsworth so in terms of what I write and what I say 
and so on, I think that I am comfortable that there is an authenticity and a legitimacy about what I feel and say and so on. It sometimes upsets me that for people who do not have that experience to write as authoritatively as they do. Let me qualify that, I think that there is a lot of exceptional research that is happening by people who may not have a direct connection there. But there is something about a voice or a lived voice that I think that people like me or of my generation have that what we feel so deeply about.

This raised a broader philosophical debate about who has the right to write history. The Dalits in India claim that only they can write their history from an insider perspective; the Aboriginals in Australia and Canada make similar claims (See Kumar 2013 and Kumar 2010). The disputations and debates over representation are complex. While I respect this perspective, I also hold that one cannot put a hermeneutic seal around interpretation. There is no one authentic voice in any situation. As Sean Field (2012:19) points out, it is 'not that the outsider cannot say anything about 'the Other' but rather that all researchers, outsiders, and insiders must try to understand how their identities and research strategies are shaping informants' and interviewees' responses'. Field (2012: 19) adds that 'even when all the identities of the researcher and researched are identical, unequal power relations exist. There is no power-free research nirvana to be reached'.

While an 'outsider,' I tried to make up for this by attending the weekly meetings of the Durban Municipal Pensioners' Club during 2013 and 2014. During these meetings I spoke to many former residents and listened to the way in which they told stories to me about what life was like in the Magazine Barracks. I also observed the ways in which they reminisced with one another, and the meanings that the barracks have for them today. I also conducted oneon-one qualitative interviews with those who volunteered.

The advantages and shortfalls of oral history methodology have been widely discussed.

As Ciraj Rassool (2010: 82) points out, some researchers are sceptical:

In spite of their commitment to the democratising power of oral history, for many South African social historians, it constituted only a 'supplementary source'. Its purpose was to supplement more formal /written sources 'which provide the larger context of public events, of 
political and constitutional, economic and institutional developments'. Human memory in the form of oral testimony was 'given to error, misconception, elision, distortion, elaboration and downright fabrication.

Field (2012: 4) puts it slightly differently but makes the same point, that historians in South Africa 'still view oral history as a supplement to historical research, which draws primarily on written sources, but occasionally turns offstage to drag in interviews to provide vibrant colour to the serious business of history'. Historians who believe in the written word should remember that archival sources also represent particular viewpoints and that oral sources may represent different but equally important alternatives. Documentary sources are not necessarily more accurate in reconstructing the past. Oral history provides a different kind of historical knowledge, one that is not static but reveals how changing contexts are experienced.

While acknowledging the limitations of oral sources, archival and other documentary sources were also consulted. However, ordinary individuals' perspectives are indispensable to understand the impact of the GAA from the viewpoint of those affected. During the 1980s, the emergence of so-called radical scholarship, inspired by Marxism, aimed to uncover the 'submerged agency of ordinary people and give voice to the experience of marginal groups'. Since such voices were often excluded from official archival documents, social historians sought to write history 'from below' to create a counter narrative to the official history (Rassool 2010: 84).

Field (2012: 2) suggests that oral history interviews are less about events and more about the meaning behind these events for the narrator. Events become memories in the mind, an ever changing group of thoughts, images, and emotional responses. Oral sources tell us not just what people did, but what they wanted to do, what they believed they were doing and how they think they did do it (see Portelli 1991). It is for this reason that oral history was such an essential tool for this study. Those who embrace oral history recognise that it is a subjective methodology and acknowledge that 'memory stories are contingent and often fluid' but believe that this 'in no way detracts from their veracity and utility'. Rather, the stories add experiential and memory value to actual historical events and fill out such events with meaning and significance. By engaging these stories, oral historians have, in the words of Abrams (2010:6) become both intuitive and imaginative interpreters of their materials'. 


\section{The Group Areas Act}

The aim of GAA was to achieve complete residential segregation by empowering the state to demarcate areas for exclusive occupation of specific racial groups and to enforce this through forced removals. The three largest, most famous, and well documented freestanding black townships destroyed by the GAA were District Six, Sophiatown, and Cato Manor. Iain Edwards (1991: 415) explains that these three areas have consequently 'become political metaphors for urban dispossession and resistance' in South Africa. However, as Saul Dubow (2014: 59) points out, 'no urban area remained immune from the operation of the 'Group' as bureaucrats set to work to fillet out Coloureds, Indians, and Africans in the 'non-white' sections of town and created spatial buffer zones between them'. Given its impact, the GAA has been described as an 'unparalleled example of state directed socio spatial structuring' in shaping the 'physical, social, cultural, political, and economic' landscape in South Africa (Maharaj 1997: 135) and its consequences were far reaching and multifaceted. For around four decades South Africans lived in a landscape shaped by a policy which separated them, and promoted and entrenched inequality and unequal access to resources.

While the local state had long instituted segregation measures in Durban, Group Areas intensified this process. Thousands of mainly African and Indian residents were removed from long settled communities and resettled in townships such as KwaMashu and Umlazi for Africans (see Dlamini 2005), and Chatsworth and Phoenix for Indians (see Ariyan 1999; and Hansen 2012). The predicament of Indians in Durban and coloureds in Cape Town (see Western 1981) was different from that of Africans as, historically, Indians and coloureds had settled in larger numbers on the fringes of cities, which ultimately resulted in a larger percentage of these groups being displaced during the implementation of the GAA. In fact, Indians as a group were proportionally the most affected by forced removals with around 80 per cent of Indians in Durban being relocated. Some scholars have argued that the Durban City Council's (DCC) desire to rid the city of Indians who were perceived as an economic threat to whites, played a crucial role in the development of legislation that culminated in the GAA and that the DCC utilised this Act for this very purpose (see Maharaj 1992; and Swanson, 1983). Given that force removals resulting from the GAA may have constituted the 'greatest event in the post-war history of the Indian population of Durban' 


\section{K. Gopalan}

(Freund 1995: 64) it is important to investigate how they have made the transition from areas which they made their home after indenture on the fringes of the city, to larger racially segregated townships such as Chatsworth and Phoenix.

Dubow (2007: 8) summarises the two trends which have dominated the historiography of the GAA:

For at least 25 years, from the end of the 1960s to the early 1990s, there were in South African historiography two fairly clear, mutually diverging viewpoints on the relationship between capitalism and apartheid, and their presence can still be sensed in new influential works of history. The radical revisionist viewpoint claimed that apartheid was created by and served capitalist interests that, because of the system, enjoyed access to great quantities of forced, cheap labour and state subsidies. In the view of the radical historians, the rapid growth in the South African economy during most of last century showed that segregation and apartheid were intentional and rational forms of government. The liberal viewpoint has assumed that apartheid was the result of the racist sentiments of Afrikaner nationalists, who dominated political power at least after the Pact government of 1924, and that, contrary to the opinion of revisionists, the system has slowed down economic growth.

While there is debate on the extent to which human agency applies, especially with regard to how South Africans responded to the laws imposed upon them by the state, this paper takes the approach suggested by Kata Uusihakala (2008: 4) that although 'historical forces such as colonialism have shaped and continue to shape the lives of people globally, they are always reflected upon and given meanings in culturally specific ways'. Understanding the means in which South Africans affected by Group Areas responded to the structural forces imposed upon them is crucial to understanding the multifaceted impact of the GAA.

Etienne Nel (1990: 1) has pointed out that 'geographic space in South Africa has been subsumed to the dictates of the prevailing political ideology of apartheid' to such a great extent that 'structure manifested by both the economy and the society reflects the ideals striven for by the architects of apartheid'. However many victims of forced removals, such as residents of the Magazine 
Barracks have defined in their own ways what state created housing meant to them and created their own meaning of state laws. Although the Magazine Barracks was created to house a labour force to serve the labour requirements of the DCC, residents in their own way created a space which became crucial to their identity and which is revered today. Likewise, the move to Chatsworth did not create residents who functioned in coherence to the state's aims of geopolitical engineering. In order to examine the impact of the GAA on former residents of the Magazine Barracks it is necessary to examine why the Magazine Barracks were constructed and what it came to mean to its residents over time.

\section{Durban's Indian Municipal Employees}

Although indentured labourers who were brought to Natal from India between 1860 and 1911 are known primarily for their role on the sugar plantations, a significant number were employed by the municipality as well. With Durban and Pietermaritzburg establishing themselves as the major urban centres in Natal, they employed indentured workers to perform tasks such as street sweepers and night soil removers. Between January 1864 and July 1907, 1437 indentured Indians were allocated to the Durban municipality. ${ }^{1}$ When the first Indians arrived in Durban to work for the municipality there was no housing and they consequently found accommodation in informal settlements such as Bamboo Square on the Point, a narrow strip of land next to the entrance of the Bay of Natal (Kearney 2002: 30). Located close to where they worked, this was an ideal location for the newly-employed Indian municipal workers.

By the 1870s the settlement included Tsonga, Indian, St Helenian, Chinese, Malay, Mauritian, and African workers (Kearney 2002: 30 - 31). From 1874, when the Secretary of Native Affairs, Theophilus Shepstone, introduced the togt or day labour system, Zulu workers who were employed by the municipality also found accommodation at Bamboo Square (Home 1998: 48). The rapid urbanisation of black people and their living in informal settlements was of concern to the DCC and the white electorate. In 1866, the Borough Police wrote to the DCC to express concern about Bamboo Square, and pointed to 'at least seven other locations' where Africans and Indians lived

1 This is according to the official Ship Lists. For a discussion on the construction of the Ship Lists, see Vahed and Waetjen (2014). 


\section{K. Gopalan}

alongside each other. In 1870 Councillor Tyzack called for a separate location for Indians due to 'evils' arising out of overcrowding at Bamboo Square. He regarded this as 'a serious matter with these Indians whose habits generally are not conductive to health' (cited in Kearney 2002: 32). Although these concerns were expressed in language about health and sanitation, this period coincided with the arrival of Indian traders, known as passengers, which increased fears of a rapid increase in the urban population and made it more urgent to control Indian settlement in the city. The DCC's solution to this perceived fear of urbanisation of blacks, was to create barracks-type accommodation for its employees.

In 1874, land was purchased just north of the Durban CBD on the Eastern Vlei. It was named the Magazine Barracks after a nearby military complex which stored magazine powder (ammunition). The Magazine Barracks was completed in 1884 and the original building comprised of 93 tiny 'houses,' with 26 allocated to married men and 67 to single men (Home 1998: 48). Each house comprised of a single room, roughly five metres by five metres in size, which had to be used as a kitchen, dining room, lounge and bedrooms. The entire complex was fenced, with two gates which were locked at night and guarded by Indian sirdars who were employed by the DCC to enforce law and order within the Magazine Barracks (Murugan 1998: 14). Two single men or one family lived in each house, regardless of the number of children per family. According to former resident Danny Pillay (2012), in later years, families were very large, with up to 15 children and it was not uncommon to find children sleeping on the kitchen floor or even outside on the balcony in summer. As the number of residents increased and children grew up, married couples had no option but to share rooms with other family members as their low income did not allow for private renting. They erected curtains across the rooms for privacy. The early wood and iron structures lacked electricity or running water and residents relied on communal taps and toilets. In 1928, the Indian Social Services Committee (ISSC), an organisation formed by educated and professional class Indians who were keen to 'uplift' the social condition of poorer Indians, reported that residents had to bathe in toilets with no doors (Vahed 1995: 83 -84), while Swaminathan Gounden (2002: 13) a former resident of the Magazine Barracks, recalled that as many as 'twelve people could be using these toilets in full view of one another' at a time'.

The barracks were ideal for the DCC since they were cheap to build 
and maintain, and were ideal to teach and maintain discipline. This is reflected in a 1935 DCC report:

Apart from the economies obtained from the provision of communal sanitary washing and bathing blocks, there are undoubted advantages in having an adequate labour supply available at any hour for emergency work, and the possibility of following up all cases of absenteeism as they arise. A further advantage is the continuous supervision which is only possible in large barracks or compounds and we are further of the opinion that the training and control they receive under that system must be beneficial to the Indians themselves ... Would the provision of cottage type of house - the presumptive alternative - not constitute an unnecessary incentive to the increase of the size of families? (cited in Vahed 1995: 83).

Although the design of the barracks and its living conditions were dictated by the utilitarian purposes of the DCC, residents responded to these conditions in their own means and created a powerful identity associated with the Magazine Barracks. Every participant who lived in the Magazine Barracks that was interviewed for this study stated that they were 'very happy' when they lived in the Magazine Barracks and explained that they missed the rich cultural and community life. Many stated that if it was possible to go back, they would. For example at the end of her interview when asked if there was anything that she would like to add, Mrs Pillay (2013) stated, 'if the place was big enough and if it was possible to go back, we would really want to go back'.

Rather than focus on poverty and overcrowding, interviewees described strong notions of sharing, family, and closeness, which they miss today. Siva Kugesan (2013) spoke of the strong culture of sharing as residents saw themselves as part of 'one large family'. She added that neighbours would often eat together or exchange food. Many other former residents highlighted this that although most were poor, they rarely went hungry because people were willing to share food and it was common for children to visit neighbours' houses to do so. John Kisten (2012), who lived at the Magazine Barracks for over 30 years, said that 'we lived as one big loving community. There was so much of love, understanding and respect, we respected our elders. It was very, very nice'.

Most residents spoke about their 'progressive nature' which they deve- 


\section{K. Gopalan}

loped to help cope with poverty by working together. Indian municipal employees established their own trade union called the Durban Indian Municipal Indian Employees Society (DIMES), and residents of the Magazine Barracks established many voluntary bodies such as the Friends of the Sick Association (FOSA), a Child Welfare Committee, St John Ambulance and the Red Cross First Aid, amongst others, to help one another. In addition they took advantage of their surroundings to find ways to supplement their income. For example, some men partook in fishing, and women found employment as domestic workers or sold fruit and vegetables.

Consequently, when former residents speak about the Magazine Barracks in the present their accounts are characterised by nostalgia. For example, Deena Muthen (2012) recalled ...,

There was such tremendous love. Yes, but you still get the harmony, in Magazine Barracks the harmony was there, Oh yes, there was that harmony, I wish I could explain to you... there was such a tremendous love amongst our people, I wish I could see that now. Everything was available there for us, the beaches were nearby, the shopping centres were nearby, the Durban Market was nearby, the cinemas were nearby.

\section{Relocation to Chatsworth}

On 12 December 1958, the DCC purchased land in Umhlatuzana, 20 kilometres south west of the Durban CBD, for the construction of approximately 14000 houses to accommodate Indians who would be displaced during the implementation of the GAA. Umhlatuzana included the farming districts of Chatsworth, Cavendish, Welbedacht, Witteklip, Buffelsbosch and Zeekoe Valley, as well as three private Indian townships, Silverglen, Kharwastan, and Umhlatuzana. Combined, this area would come to constitute the Chatsworth Indian Township which comprised of 89 acres, 61 acres of which was suitable for housing (see Subramony 1993; Vahed 2013). The bulk of the housing was low cost, utilising cheap materials and maximum space. By the early 1960s, after several unsuccessful court challenges, residents of the Magazine Barracks came to realise that they would have vacate what had been a home for thousands, for close to eight decades and be relocated to different areas in Chatsworth. 
Whereas most regarded the barracks as their home and had a strong attachment to it, to their neighbours, and to the broader Magazine Barracks community, former residents pointed out during interviews that they always knew that they could not stay there permanently. Other than space problems which grew worse each year, residents did not own the land or their houses and faced eviction when they were no longer working for the municipality. Having said this, the respondents also pointed out that they anticipated leaving the Magazine Barracks gradually at some future date and of their own volition. The DCC's decision to forcibly resettle them in the distant and unfamiliar Chatsworth was not something they had foreseen.

The move to Chatsworth also proved expensive for both residents who had to rebuild their lives in the new setting and the DCC which struggled to keep pace with service delivery demands. At the Magazine Barracks, residents had paid just 86 cents in rent, while their employer provided paraffin and wood rations and they lived within walking distance of work. In Chatsworth, residents had to pay more than double in rent, had to pay for electricity and water, had to buy electric stoves, and had to pay for transportation to and from the city to work, do shopping, and to visit relatives and friends. Pillay (2013) pointed out that, in contrast to the Magazine Barracks where residents had built a community over many decades, Chatsworth in the 1960s was a bare housing scheme 'with no public amenities, no infrastructure such as roads, schools, shops, temples or mosques, sports fields or community centres'.

While the pay was low at the Durban Corporation, some found ways to improve their situation. The interviewees noted that while some workers chose to remain in low paying positions, for those who were determined, there were ways to climb the ladder to higher positions. Many respondents, who spoke about their climb up the ladder within the municipality, narrated their experiences as part of a 'progressive nature' that was developed when they lived in the Magazine Barracks. For example when narrating how he managed to work his way up in the Durban Corporation Naddie Perumal (2013) explained 'once you are in the Corporation, a lot of people, found ways to improve themselves'.

Although the opportunities to supplement their incomes which existed in the CBD disappeared in Chatsworth, some residents found ways to do so in the new environment. Vassie Muthen said that this was because of the 'progressive nature' and 'resourcefulness' that was developed at the Magazine Barracks. He added that although residents lived as one big family and treated 


\section{K. Gopalan}

one another as 'brother and sister' they were also 'brought up to live independently'. For him, it was this 'upbringing' which led to some finding creative ways to become 'small time entrepreneurs,' when they arrived in Chatsworth. For example, due to the absence of retail stores, some residents of the township started tuck shops at their houses which provided daily essentials. V. Muthen and his wife sold milk, bread, sugar, tea, and other items, while others opened barbershops (hairdressing) or car repair workshops.

Speaking of how his grandmother adapted to conditions in Chatsworth after relocation from the Magazine Barracks, Kiru Naidoo (2012) recalled,

I think her strongest contribution in all of this was that she was a woman really ahead of her time, very entrepreneurial, entrepreneurial with really nothing. She had nothing to begin with but she really made a great deal with nothing. She set up a tuck shop at home, I mean now we call it a tuck shop but she was literally a woman with a box of eggs and cigarettes .... They [elder generation] spent very little, very frugal people but very, very high, exceptional rates of savings to be able to do this. So I think she had that matriarchal quality about her. If there were the right sort of political circumstances, I am more than certain that my granny would have been a millionaire. You know apartheid presented obstacles for her. If she had the slightest of opportunities, she would have been phenomenal. She just had a way and this is a woman who has never been in a classroom, who couldn't even read or write Tamil but had, I think of it as a generosity of heart and spirit. She grew up [raised] so many people..... So there is that element of it. So if we talk about Chatsworth, as a story of triumph.

Whereas forced removals are often seen in the literature as creating 'victims,' many removed from the Magazine Barracks emphasised how they and their families overcame difficult odds. John Kisten explained that instead of facing the situation as powerless victims, most of the removees accepted the inevitable and tried to make the best of their predicament. Although it was difficult in the early years, the residents concentrated on making the best of it and this enabled them to improve their circumstances considerably. In this regard, moving to Chatsworth provided much-needed improvement to the situation that existed in the Magazine Barracks where the space problem would have been compounded. Kisten said that once residents got over their initial 
'shock' and 'sadness' of being displaced from their homes and split from their neighbours, 'instead of just sitting and moaning and groaning, we thought let's see'. For Kisten it was this attitude and the progressive nature of former residents that enabled them to succeed. He added that had they remained in the Magazine Barracks it would have been difficult because families could not be accommodated in the overcrowded conditions for much longer. In his work as a priest, he was often called upon to offer prayers when a former resident of the Magazine Barracks made a purchase like a car or some other major investment and he said that it gives him great pride because at the barracks, only two people owned cars.

V. Muthen supported this:

In my voluntary work I do a lot of visits to these families, also because of my religious work at Magazine Barracks Shree Vishnu Temple, because of my religious work and social activities and being a chairman of the Durban Municipal Pension Fund and also being a secretary in the Magazine Barracks Remembrance Association, I use to go interview people on how they progressing, what their fathers and mothers use to do in Magazine Barracks and all that. Checking their past and checking their future and how they come up from and how they are moving up the ladder now, the progress is tremendous. I am not speaking bad about Magazine Barracks, I am one proud of the member of the Magazine Barracks. But I am sorry if they stayed in that same communal living they wouldn't be where they are now. They would be very happy and would progress in a small way, but they wouldn't progress to the extent that they progressed now.

This long quote captures an important theme that emerged during many of the interviews. The loss of communal living, although lamented by former residents of the Magazine Barracks, also meant economic progression and a 'modern way' of life. The initial hardships of Chatsworth were difficult but from a longer term perspective it allowed former residents to move out of a closely confined space and provided them with new opportunities.

When discussing the social and cultural impact of moving to Chatsworth former residents of the Magazine Barracks also exhibited notions 'comparative memory,' where they compared life before forced removals to life after forced removals. In this instance, they ignored or downplayed the 


\section{K. Gopalan}

disadvantages of their settlements before forced removals, which they then contrasted with the settlements after relocation. For example, when asked about poverty or violence in the Magazine Barracks, former residents explained that although it existed, it was under control, unlike what happened in Chatsworth. In the Magazine Barracks, poverty was described fondly as something that promoted sharing and communal bonds. In Chatsworth, poverty in the initial years was described by something that was unfamiliar and created unbearable hardship. Violence too was depicted this way. Referring to gangsterism that existed in the Magazine Barracks, Perumal (2013) explained that,

The gangsters, big gangsters too, they don't just fight for nothing unless there was a good reason. They were very helpful like, they help each other, you know I told you they were like a community like, like one family like. They never see somebody getting hurt or falling down or something, they take him home put him in bed. That is what they do, they help each other. But here in Chatsworth, all that is gone.

He added that when they came to Chatsworth and were split up, the discipline fell away. There was 'no unity', they started going their own way and there were fights between rival gangs.

\section{Remembering the Magazine Barracks}

An important component to examining Group Areas is to investigate how the forced removals are remembered and whether and how they are commemorated. Despite the vast body of literature on forced removals, until recently the perspectives of ordinary people were largely ignored, with most emphasis on government policy and an excessive focus on victimhood. Museums such as the District Six Museum in Cape Town and South End Museum in Port Elizabeth allow people to tell their own stories (see Kadi 2007). Much thought and planning has been put into these projects, and they try to capture memories of anti-apartheid activism and the effects of forced removals through interviews, photographs, and newspaper reports. In the South End Museum one gets the sense of a multi-racial, close-knit community destroyed by Group Areas.

What of Chatsworth? One cannot speak of 'Chatsworth' as a homo- 
genous unit but rather of attempts to institutionalise memories of the Magazine Barracks through the MBRA. The MBRA was established in 1997 in response to the new ANC land restitution programme. The act which aimed to 'produce reconciliation and 'healing' of the country through the return of, or compensation for, lost land rights' and was administered by the Commission on Restitution of Land Rights (CRLR) (Bohlin 2007: 118). As Anna Bohlin (2007: 127-128) argues, although the CRLR aimed to address the past suffering and injustice carried in living memory by those who were personally affected, the impact of the commission has been academically analysed almost exclusively in terms of its legal, administrative, and organisational dimensions. Missing from the literature are the ways in which land claims have led to people engaging with the past in new ways, and consequently the production of new memories.

In order to claim compensation for land lost, those who were forcibly displaced under apartheid were required to provide documentary evidence of their dispossession. Many people provided old photographs and oral testimonies situating their personal experience of displacement in a grander narrative of GAA removals. For Bohlin, one important 'side effect' of this process has been the production of a collective memory. Bohlin's study of Kalk Bay, a small fishing community in the Western Cape, found that since only a small number of residents were forced to relocate (around 120 people, mainly Coloureds and Indians), many residents were not even aware that Kalk Bay was affected by Group Areas and the land claim process was important in producing a new collective memory.

In the case of the Magazine Barracks, as with other areas affected by the GAA, this was a lived experience for thousands. Even before the ANC government's land restitution programme there were active attempts amongst former residents to preserve some form of Magazine Barracks memory despite, and because of obstacles such as the separation of neighbours. The recreation of places within and around the Magazine Barracks in Chatsworth such as the Chatsworth Magazine Barracks Shree Vishnu Temple and the naming of the Depot Road Memorial School are examples. Soccer clubs and other social 'clubs' such as school committees were ways in which residents attempted to maintain the bonds and linkages that had existed at the Magazine Barracks. The activities of the MBRA are different in several ways. In the first instance, these identities are being produced in a different context. For example, in the post-apartheid period, there are fears of marginalisation amongst Indians and 


\section{K. Gopalan}

this process provides a means of communal identity. Also different is that over the decades many of the former residents of the Magazine Barracks acquired professional qualifications and other skills and this social capital was important in organising the community and preparing relevant documentation. The various mass meetings of residents over the past 15 years helped to forge a collective memory amongst former residents who were able to actively reminisce with one another about the 'good old days'. Nostalgic recollections of the values and benefits of communal living at the Magazine Barracks and a narrative of progression and upliftment of community were promoted at such meetings.

Leaders in the MBRA who spoke of the origins of the association situate its existence in the collective drive to help one another in any way possible; a trait that they say existed at the Magazine Barracks. This is evident in V. Muthen's (2012) recollection of the origins of the MBRA

Then when we came to Chatsworth, then we fought, we fought very hard, the Magazine Barracks Remembrance Society fought very hard. It was one day when I was sitting here at home, and then a call from the late Captain Marimuthu. He said, 'Ah what are we doing, we are sitting back and not even thinking of collecting some sort of compensation for being forcibly removed from Magazine Barracks'. And he put me on to a female lawyer, Samba who was from Magazine Barracks. As a young girl she was there and then she qualified as a lawyer, and then I phoned Danny, and then a long conversation and then with our late secretary, and we said we have to help those who are in need and cannot do this on their own. Our late secretary [Nelson Veerasamy] and Danny together worked tooth and nail, they worked very hard, they worked very hard.

Although forced removals were effected in the early 1960s and the MBRA was only established in 1997, V. Muthen's narrative, and those of others, point to the idea of continuity. V. Muthen added that after they started the organisation they had to interview families to get the details and documentary evidence from each of those that were resettled. This was a mammoth undertaking and members of the committee personally conducted interviews with those who were displaced. Kisten (2012) pointed out that it would have cost thousands of rand for each family if they had got outsiders to compile the documentation 
and that is why they volunteered. For example, Deena provided his services as a commissioner of oaths and D. Pillay would leave his business early to help sort out documents. Kisten (2012) said that they did it 'out of love for our community .... We got the documents, we went out of our way to make sure they were in order, and we never charged our people... You will go throughout the world and you will never find a community like that'.

In 1998 the association organised sessions at the New Bethesda Church Hall, the Chatsworth Youth Centre, and the Greenvale Primary School to conscientise former residents about the process and to help them prepare their applications. Representatives of around 2000 displaced households from the Magazine Barracks came forward and these applications were submitted to the KwaZulu Natal Lands Claims Commission on 17 December 1998 with payments made from 2003. Not everyone was happy as some claims were rejected and successful claimants were paid R20 000 each as opposed to the R50 000 paid to other claimants because they did not own the land at the Magazine Barracks. The human suffering was not given appropriate weight.

Although initiated for the purpose of land claims, the process and the MBRA became a platform to promote the memory of the Magazine Barracks amongst a younger generation. Discussing the origins of the Association, Deena emphasised its importance in preserving bonds which once existed and the notion of one large Magazine Barracks 'family,' something that was lost because of their dispersal to various units in Chatsworth. While the idea of being a 'family' at the barracks is itself nostalgic, Deena believes that 'we were no more that one family. Now to keep that thing going we started the Magazine Barracks Remembrance Association... to 'get the people together, to come together to eat supper, keep that family unity'.

The Association has several ideas to ensure that these memories will not be lost. One is to compile a book to remind future generations of 'where they came from,' in Kisten's (2012) words. During the land claims procedure, many families had to dig into their past and tracked their ancestors and the history of their families. They also charted the financial improvements made by families after they settled in Chatsworth, which was seen as a story of triumph. Unfortunately, this process was delayed by the death of their secretary Nelson Veerasamy in 2008 and they have not been able to locate all the information which was gathered from these interviews.

Another project that the founders of the MBRA have in mind is to build a hall and house a museum within it. D. Muthen (2009) said that, 


\section{K. Gopalan}

Danny is looking for an area where we can purchase land - we want to bring back something in Chatsworth that would be a memory, a legacy, you know, that future generations will know where their grandparents and their parents came from - the Magazine Barracks because that place where we lived, every person was very, very, very culturally, culturally orientated and it's so unfortunate that we were put into this place - Chatsworth - we've lost our culture.

Respondents born at the Magazine Barracks and interviewed for this study, as well those who spoke during the many municipal pensioner meetings emphasised that the notion of a 'Magazine Barracks identity' was, and still is, important to them. This also applied to children of residents of the Magazine Barracks who were born in Chatsworth. For many of them, the Magazine Barracks remains a focal point of reference. For example, Naidoo (2012) said that his parents and grandparents saw the Magazine Barracks as an 'exclusive club'. When they spoke to each other 'they reminisced about the districts in which they use to live'. While Naidoo is open to people of all race, religious and class backgrounds, he too believes that there is that unidentifiable something that binds them together.

Most former residents believe that the GAA destroyed their rich and close-knit community even while facilitating material progress for many and providing a solution to the severe overcrowding at the Magazine Barracks. V. Muthen (2012) and others believe that unlike most others who were resettled in Chatsworth, the former residents of the Magazine Barracks are unique in that they did not lose their attachment completely and that this has strengthened in recent years.

Kisten (2012) supported the notion of a Magazine Barracks identity which helped residents to overcome some of their challenges in Chatsworth in the past and the present: 'if I hear someone [from Chatsworth] has a problem, I run to assist because we came from that humble beginnings. We have not forgotten our roots,' he said in reference to his voluntary civic work in Chatsworth. D. Muthen (2012) also said that the voluntary schools, medical clinic and feeding schemes which he runs today at no charge are the result of his upbringing at the Magazine Barracks and the ethos of community self-help that was ingrained in him by his father who always taught his children to serve others. 


\section{Conclusion}

The story of Indian municipal workers since the 1870s shows how their living conditions were constantly shaped by the racist capitalist forces which so fundamentally determined the trajectory of South Africa's social, economic, and political growth. The Magazine Barracks was primarily established to enable the DCC to have a cheap and manageable labour force at their disposal. However, residents made it into their home. Indian municipal employees were not passive victims, but took advantage of their situation and created a powerful identity associated to the Magazine Barracks.

Although many outsiders assign pejorative connotations to the term 'barracks' and its residents, for its former residents it is a term that is revered and holds special value because it is a reminder of their 'humble beginnings,' as some respondents put it, and how so many of them 'progressed' despite their difficult circumstances. This supposedly intrinsic quality of seeking to succeed against all odds helped the residents to cope with life at the Magazine Barracks and they felt that it also helped many to improve themselves materially in Chatsworth. However, it was not individual success but the community working together which helped uplift many in the process. Respondents describe their family histories as a kind of 'rags to riches' story. This 'success' and progress is crucial to the identities of interviewees.

The former residents of the Magazine Barracks were also keen to emphasise that it was impossible for an outsider to understand what the barracks meant to them, particularly the passion and camaraderie that existed there.

The Magazine Barracks produced a powerful shared experience, albeit a racially exclusive one in relation to Africans, but also one where the former residents of the barracks are keen to counter the stereotypes that other Indians have of them, associating them with 'thuggery' and 'violence' and the general negative qualities of being working class. They ignored and downplayed the disadvantages of their lives before forced removals and portrayed the barracks in a positive light as a place of prestige to have come from.

During the 1960s when the Group Areas proclamations were implemented in Durban, the Magazine Barracks was home to nearly 10000 people. Apart from the practical benefits of living near to the city centre where municipal employees worked, residents resented vacating what had been their home for so many years. This they had in common with the millions of others affected by the GAA. Some former residents stated that what alarmed them 


\section{K. Gopalan}

most was being split from their neighbours who they regarded as family. Houses with running water and electricity eventually appealed to some following their relocation to Chatsworth, even though most residents were unhappy about being forcibly evicted from their homes. The NIC's ineffectiveness in challenging Group Areas, and the role played by those deemed to be 'leaders' at the Magazine Barracks in actually facilitating the move to Chatsworth minimised the anger and possible large-scale protests by residents, many of whom seemed to take the position that since they had 'no choice' they should make the best of their situation.

The physical violation of their community initially made residents of the Magazine Barracks angry and resulted in a sense of powerlessness as well as disorientation in the new township. Group Areas did not just mean that individuals were thrown out of their homes, but entire communities and a way of life which was created over decades were suddenly reduced to shreds. It is thus perfectly understandable that those were displaced spoke of their losses and described the GAA as a destructive force. Despite getting their own homes, Chatsworth was initially a bare housing scheme with no amenities. Houses were plagued with structural problems, roads were inadequate and dangerous gangs flourished. The extended family system was altered, the cost of living increased considerably, especially due to inadequate and higher transport costs, and many former residents were separated from neighbours that they had known for several generations. However, in the long term, residents were able to extend their homes and benefit from expanded educational and other opportunities, as well as running water and electricity.

Former residents speak nostalgically about the community that they created and have fond memories of growing up at the Magazine Barracks. The 'unstable' post-apartheid present seems to be producing this serene and thriving past. The move to Chatsworth was not just about material loss; underlying some of the narratives was the sense that the loss included loss of stability, friendships, family, culture, and religion, and a way of life; in other words, of self.

\section{References}

Abrams, Lynn 2010. History Theory. London: Routledge.

Ariyan, Luxien L 1999. The Impact of the Group Areas Act upon Indian South 
Africans Resident in Natal: A Historico-Phenomenological Study. PhD dissertation, University of Durban-Westville.

Dlamini, S.N. 2005. Youth and Identity Politics in South Africa, 1990-94. Toronto: University of Toronto Press.

Dubow, S. 2007. Thoughts on South Africa: Some Preliminary Ideas. In Stolten, H.E. (ed.): History Making and Present Day Politics: The Meaning of Collective Memory in South Africa. Sockholm: Nordiska Afrika Institutet.

Dubow, S. 2014. Apartheid, 1948-1994. Oxford: Oxford University Press. Edwards, I. 1991. Cato Manor: Cruel Past, Pivotal Future. Review of African Political Economy 21, 61: 415-427.

Field, S. 2012. Oral History, Community, and Displacement: Imagining Memories in Post-Apartheid South Africa. Hampshire: Palgrave Macmillan.

Freund, B. 1995. Insiders and Outsiders: The Indian Working Class of Durban 1910-1990. Pietermaritzburg: University of Natal Press.

Gounden, S. 2002. Untitled section in G. Pillay (ed.): Come to the Point: A History of the Indian Community and some Well-Known Personalities. Durban: Point Indian Remembrance Committee.

Hansen, T.B. 2012. Melancholia of Freedom: Social Life in an Indian Township in South Africa. Princeton: University of Princeton Press.

Home, R. 1998. Barracks and Hostels: A Heritage Conservation Case for Worker Housing in Natal. Natalia 28: 45-52.

Kadi, P. 2007. The Group Areas Act and Port Elizabeth's Heritage: A Study of Memorial Recollection in the South End Museum. Master's Dissertation, University of the Western Cape.

Kearney, B. 2002. Bamboo Square: A Documentary Narrative of the 'Indian and Native Cantonment' at the Point. Journal of Natal and Zulu History 20: 29-64.

Kumar, R. 2013. Exploring Convergences: Dalit writings and Australian Aboriginal Writings. Asian Journal of Humanities and Social Sciences $1: 1$.

Kumar, R. 2010. A Comparative Perspective on Subaltern Autobiographies: Dalits vs. Aboriginals. Creative Forum: A Journal of Literary \& Critical Writings 23: 1-2.

Maharaj, B. 1997. Apartheid, Urban Segregation, and the Local State: Durban and the Group Areas Act in South Africa. Urban Geography 18:2: 135- 
154.

Maharaj, B. 1992. The Group Areas Act in Durban: Central - Local - State Relations. PhD Dissertation, University of Natal, Durban.

Murugan, P. 1998. The Lotus Blooms on an Eastern Vlei. Chennai: Parkar Computers.

Portelli, A. 1991. The Death of Luigi Trastulli and Other Stories: Form and Meaning in Oral History. Albany: SUNY Press.

Subramony, K. 1993. A History of Chatsworth: Impact of the Group Areas Act on the Indian Community of Durban (1958-1975). Master's dissertation, University of South Africa, Pretoria.

Rassool, C. 2010. Power, Knowledge and the Politics of Public Pasts. African Studies 69.

Swanson, M. 1983. 'The Asiatic Menace': Creating Segregation in Durban, 1870-1900. International Journal of African Historical Studies 16: 401421.

Trotter, H. 2009. Trauma and Memory: The impact of Apartheid-era Forced Removals on Coloured Identity in Cape Town. In Adhikari, M. (ed.): Burdened by Race: Coloured Identities in Southern Africa. Cape Town: UCT Press.

Vahed, G. 1995. The Making of Indian Identity in Durban, 1914-1949. PhD Dissertation, University of Indiana. USA.

Vahed, G. 2013. Segregation, Group Areas and the Creation of Chatsworth. In

Vahed, G. \& A. Desai (eds.): Chatsworth: The Making of a South African

Township. Scottsville: University of KwaZulu-Natal Press.

Vahed, G. \& T. Waetjen 2014. Passages of Ink: Decoding the Natal Indentured Records into the Digital Age. Kronos 40: 3: 45 - 73.

Western, J. 1981. Outcast Cape Town. Cape Town: Human and Rousseau.

\section{Interviews}

Mrs. Pillay, former resident of the Magazine Barracks interviewed 15 April 2013.

Danny Pillay, former resident of the Magazine Barracks interviewed 28 November 2012.

Siva Kugesan, former resident of the Magazine Barracks interviewed 31 January 2013. 
Forced Relocations, Memory and Nostalgia

John Kisten, former resident of the Magazine Barracks interviewed 12 December 2012.

Deena Muthen, former resident of the Magazine Barracks interviewed 1 December 2012.

Vassie Muthen, former resident of the Magazine Barracks interviewed 12 December 2012.

Naddie Perumal former resident of the Magazine Barracks interviewed 5 February 2013.

K. Gopalan

Department of History University of Fort Hare KGopalan@ufh.ac.za 